\title{
Stimulation of Adenosine Receptors Selectively Activates Gene Expression in Striatal Enkephalinergic Neurons
}

\author{
Marzena Karcz-Kubicha',3, Sergi Ferré*,', Oscar Díaz-Ruiz², César Quiroz-Molina', Steven R Goldberg', \\ Bruce T Hope' and Marisela Morales ${ }^{2}$ \\ 'Behavioral Neuroscience Branch, National Institute on Drug Abuse, IRP, NIH, DHHS, Baltimore, MD, USA; ${ }^{2}$ Cellular Neurobiology Branch, \\ National Institute on Drug Abuse, IRP, NIH, DHHS, Baltimore, MD, USA
}

\begin{abstract}
In the striatum, adenosine $A_{2 A}$ and dopamine $D_{2}$ receptors exert reciprocal antagonistic interactions that modulate the function of GABAergic enkephalinergic neurons. We have previously shown that stimulation of adenosine $A_{1}$ receptors allows the stimulation of $A_{2 A}$ receptors to overcome a tonic inhibitory effect of $D_{2}$ receptors and induce striatal expression of c-fos. In the present work, by studying co-localization of c-Fos immunoreactivity and preproenkephalin and preprodynorphin transcripts, we show that co-administration of the $A_{1}$ receptor agonist CPA and the $A_{2 A}$ receptor agonist CGS 21680 increases the striatal expression of c-fos in GABAergic enkephalinergic but not in GABAergic dynorphinergic neurons. Co-administration of CPA and CGS 21680 also induced a significant increase in the striatal expression of preproenkephalin. The results underscore the role of adenosine in the activation of gene expression in the GABAergic enkephalinergic neuron.

Neuropsychopharmacology (2006) 3 I, 2173-2 179. doi: I0. I038/sj.npp. I 30 I035; published online I February 2006
\end{abstract}

Keywords: adenosine $A_{1}$ receptor; adenosine $A_{2 A}$ receptor; c-Fos; enkephalin; dynorphin; striatum

\section{INTRODUCTION}

Adenosine and dopamine modulate the activity of the striatal $\gamma$-aminobutyric acid (GABA)ergic efferent neurons, which constitute more than $90 \%$ of the neuronal population in the striatum. Striatal GABAergic efferent neurons can be classified into two major classes according to their peptide expression. GABAergic enkephalinergic neurons express dopamine and adenosine receptors predominantly of the $\mathrm{D}_{2}$ and $A_{2 A}$ subtype, respectively, while GABAergic dynorphinergic neurons predominantly express dopamine $D_{1}$ and adenosine $A_{1}$ receptors (for reviews, see Ferré et al, 1997; Gerfen, 2004).

Studies on the expression of immediate-early genes, such as $c$-fos, and of the expression of the peptide genes, such as preproenkephalin and preprodynorphin (precursors of enkephalin and dynorphin, respectively), have consistently shown a differential effect of dopamine in the two striatal GABAergic efferent neurons (Gerfen, 2004). This is due to

\footnotetext{
*Correspondence: Dr S Ferré, Preclinical Pharmacology Section, National Institute on Drug Abuse, IRP, NIH, DHHS, 5500 Nathan Shock Drive, Baltimore, MD 21224, USA, Tel: + I 410550 1586, Fax: + | 410550 1648, E-mail: sferre@intra.nida.nih.gov

${ }^{3}$ Current address: Molecular Neurotoxicology Laboratory, Department of Environmental Health Sciences, Johns Hopkins University, Bloomberg School of Public Health, Baltimore, MD 21205, USA.

Received 13 June 2005; revised and accepted 29 September 2005 Online publication: 29 December 2005 at http://www.acnp.org/ citations/Npp | 22905050385/default.pdf
}

the segregation of $D_{1}$ and $D_{2}$ receptors, whose activation stimulates and inhibits the function of GABAergic dynorphinergic and GABAergic enkephalinergic neurons, respectively (Gerfen, 2000). $A_{2 A}$ and $D_{2}$ receptors exert reciprocal antagonistic interactions that modulate the function of GABAergic enkephalinergic neurons (Ferré et al, 1993, 1997, 2003; Agnati et al, 2003) and recent studies have demonstrated the ability of $\mathrm{A}_{2 \mathrm{~A}}$ and $\mathrm{D}_{2}$ receptors to heteromerize (Canals et al, 2003; Kamiya et al, 2003; Ciruela et al, 2004; Woods and Ferré, 2005). $\mathrm{A}_{2 \mathrm{~A}}$ and $\mathrm{D}_{2}$ receptors are prototypical $\mathrm{G}_{\mathrm{s}^{-}}$and $\mathrm{G}_{\mathrm{i}}$-coupled receptors, respectively, which play opposite effects on adenylyl-cyclase (Kull et al, 1999; Hillion et al, 2002; Lee et al, 2002). Stimulation of $\mathrm{A}_{2 \mathrm{~A}}$ receptors can potentially stimulate striatal adenylyl-cyclase, with the consequent activation of the cAMP-PKA signaling pathway and the induction of the expression of different genes, such as c-fos and preproenkephalin (Agnati et al, 2003; Ferré et al, 2003, 2004). However, under normal conditions, the ability of $\mathrm{A}_{2 \mathrm{~A}}$ receptors to activate the cAMP-PKA signaling pathway is restrained by the tonic inhibitory effect of $\mathrm{D}_{2}$ receptors, which potently inhibit $\mathrm{A}_{2 \mathrm{~A}^{-}}$ receptor mediated adenylyl-cyclase activation (Agnati et al, 2003; Ferré et al, 2003, 2004). We have shown that activation of adenosine $A_{1}$ receptors allows $A_{2 A}$ receptors to overcome the inhibitory effect of $\mathrm{D}_{2}$ receptors and induce striatal expression of $c$-fos (Karcz-Kubicha et al, 2003). However, it remained to be demonstrated if this increase in $c$-fos expression takes place in GABAergic enkephalinergic neurons. 
In the present work, we used a combination of immunohistochemistry, to detect c-Fos (a cellular marker for neuronal activation), and in situ hybridization to determine the phenotype (enkephalinergic or dynorphinergic) of striatal neurons activated by co-administration of $A_{1}$ and $\mathrm{A}_{2 \mathrm{~A}}$ receptor agonists.

\section{METHODS}

\section{Subjects and Drugs}

Male Sprague-Dawley rats (Charles River Laboratory, Wilmington, MA, USA), weighing 300-350 g were used in all experiments. Animals were maintained in accordance with guidelines of the Institutional Care and Use Committee of the Intramural Research Program, National Institute on Drug Abuse, NIH. The $\mathrm{A}_{1}$ receptor agonist $N^{6}$-cyclopentyladenosine (CPA) and the adenosine $\mathrm{A}_{2 \mathrm{~A}}$ receptor agonist 2- $p$-(2-carboxyethyl)phenethylamino- $5^{\prime}-N$-ethylcarboxamidoadenosine (CGS 21680) were purchased from Sigma Chemical Company (St Louis, MO, USA). Both drugs were dissolved in sterile saline and administered intraperitoneally (i.p.) in a volume of $2 \mathrm{ml} / \mathrm{kg}$ of body weight.

\section{In Situ Hybridization and Immunocytochemistry}

At $2 \mathrm{~h}$ following the administration of drugs, rats were anesthetized with Equithesin (NIDA Pharmacy, Baltimore, MD, USA) and perfused transcardially with a solution of $4 \%$ (W/V) paraformaldehyde in $0.1 \mathrm{M}$ phosphate buffer (PB), $\mathrm{pH}$ 7.3. The brains were postfixed for $2 \mathrm{~h}$, immersed in $20 \%$ sucrose in $\mathrm{PB}$ overnight and frozen in powdered dry ice. Sections were cut at $30 \mu \mathrm{m}$ thickness and stored frozen in cryoprotectant (Morales et al, 1998). Phenotypic characterization of enkephalinergic and dynorphinergic neurons was carried out by in situ hybridization as previously described (Backman et al, 2001). Sections were washed three times in $\mathrm{PB}$, incubated for $10 \mathrm{~min}$ in $\mathrm{PB}$ containing $0.5 \%$ Triton $\mathrm{X}$ 100 , rinsed $2 \times 5$ min with $\mathrm{PB}$, treated with $0.2 \mathrm{~N} \mathrm{HCl}$ for $10 \mathrm{~min}$, rinsed $2 \times 5 \mathrm{~min}$ with $\mathrm{PB}$, and then acetylated in $0.25 \%$ acetic anhydride in $0.1 \mathrm{M}$ triethanolamine, $\mathrm{pH} 8.0$ for $10 \mathrm{~min}$. Sections were rinsed $2 \times 5 \mathrm{~min}$ with $\mathrm{PB}$, postfixed with $4 \%$ paraformaldehyde for $10 \mathrm{~min}$, and after a final rinse with $\mathrm{PB}$ were hybridized at $55^{\circ} \mathrm{C}$ for $16 \mathrm{~h}$ in hybridization buffer $(50 \%$ formamide; $10 \%$ dextran sulfate; $5 \times$ Denhardt's solution; $0.62 \mathrm{M} \mathrm{NaCl} ; 50 \mathrm{mM}$ DTT; $10 \mathrm{mM}$ EDTA; $20 \mathrm{mM}$ PIPES, pH 6.8; 0.2\% SDS; $250 \mu \mathrm{g} / \mathrm{ml}$ ssDNA; $250 \mu \mathrm{g} / \mathrm{ml}$ tRNA) containing $10^{7} \mathrm{cpm} / \mathrm{ml}$ of each $\left[{ }^{35} \mathrm{~S}\right]$ and $\left[{ }^{33} \mathrm{P}\right]$ preproenkephalin or preprodynorphin riboprobes (original plasmids were kindly provided by $\mathrm{Dr}$ Sabol, NIH). A 422 bp cDNA fragment (nucleotides 314-736, Accession \# NM 001002927) was transcribed with T3 RNA polymerase to generate a radioactive antisense preproenkephalin riboprobe. A $1.4 \mathrm{kbp}$ fragment (nucleotides 2700-1300, Accession \# NM-018863) was transcribed with SP6 to generate a radioactive antisense preprodynorphin riboprobe. At $1 \mu \mathrm{g}$ of linearized cDNA template was transcribed with their respective RNA polymerase $(20 \mathrm{U}$, Roche, Indianapolis, IN) in $1 \times$ transcription buffer containing $10 \mathrm{mM}$ dithiothreitol (DTT), $40 \mathrm{U}$ ribonuclease inhibitor with $100 \mu \mathrm{Ci}^{35} \mathrm{~S}$ labeled UTP, or $125 \mu \mathrm{Ci}{ }^{33} \mathrm{P}$-labeled UTP ${ }^{35} \mathrm{~S}$-labeled specific activity $1250 \mathrm{Ci} / \mathrm{mM} ;{ }^{33} \mathrm{P}$-labeled specific activity
$3000 \mathrm{Ci} / \mathrm{mM}$, Perkin-Elmer, Boston, MA), $1.5 \mathrm{mmol}$ each of rATP, rCTP, and rGTP in a volume of $20 \mu$ l. Transcription reactions were carried out at $37^{\circ} \mathrm{C}$ for $120 \mathrm{~min}$ with the addition of $20 \mathrm{U}$ of RNA polymerase at $60 \mathrm{~min}$. Complementary RNA probes were purified by gel filtration column chromatography (Roche, Indianapolis, IN).

Sections were rinsed in $2 \times$ SSC before incubation with RNase A at $4 \mu \mathrm{g} / \mathrm{ml}$ at $37^{\circ} \mathrm{C}$ for $1 \mathrm{~h}$, washed with $1 \times \mathrm{SSC}$, $50 \%$ formamide at $55^{\circ} \mathrm{C}$ for $1 \mathrm{~h}$, and with $0.1 \times \mathrm{SSC}$ at $68^{\circ} \mathrm{C}$ for $1 \mathrm{~h}$. After this last SSC wash, sections were rinsed with PB buffer and then incubated in $4 \%$ bovine serum albumin supplemented with $0.3 \%$ Triton-X-100 in PB for $1 \mathrm{~h}$ followed by incubation with a polyclonal anti c-Fos antibody (Santa Cruz Biotechnology, Santa Cruz, CA) at 1:1000 dilution for $24 \mathrm{~h}$ at $4{ }^{\circ} \mathrm{C}$. Sections were processed with an $\mathrm{ABC}$ kit (Vector) and peroxidase activity was revealed with $0.003 \% \mathrm{H}_{2} \mathrm{O}_{2}$ and $0.05 \%$ 3,3-diaminobenzidine-4 $\mathrm{HCl}$. Brain sections were mounted on coated slides, dehydrated in ethanol, treated with Histoclear, rinsed in $100 \%$ ethanol and exposed to BAS-MS 2025 imaging plates (Fujifilm, Stamford, CT) for multiple exposure times to determine the linear range of detection and produce clear images using a BAS-5000 imaging plate scanner (Fujifilm, Stamford, CT). Thereafter, sections were dipped in nuclear track emulsion and exposed for several weeks prior to development. Two sets of experiments were performed and analyzed independently. The first set included a group treated with saline (control) and a group treated with CGS $21680(0.5 \mathrm{mg} / \mathrm{kg}$, i.p.) plus CPA (0.3 mg/kg, i.p.). The second set included three groups, treated with either saline (control), CGS 21680 $(0.5 \mathrm{mg} / \mathrm{kg}$, i.p.) or CPA $(0.3 \mathrm{mg} / \mathrm{kg}$, i.p.).

\section{Image Analysis}

Two types of analysis, at two different levels of magnification, were performed. At the lower magnification level, the total number of c-Fos positive nuclei and the averaged hybridization signal were measured from the areas of the Nucleus Accumbens (NAc) and Caudate-Putamen ( $\mathrm{CPu})$ shown in Figure 1. For quantification of c-Fos immuno-

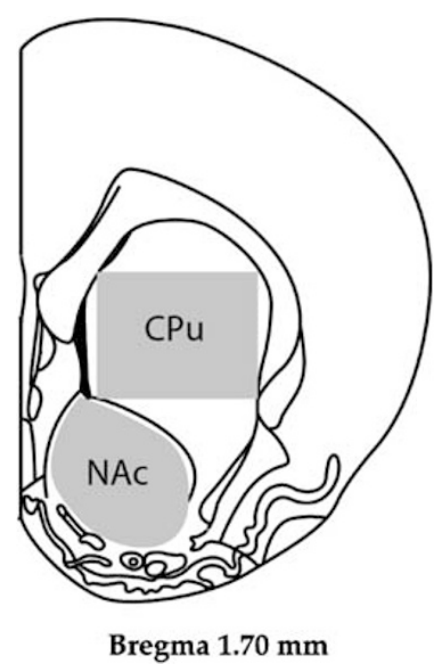

Figure I Scheme of rat brain section showing the level of the brain areas analyzed for c-Fos immunohistochemistry and preproenkephalin or preprodynorphin mRNA in situ hybridization. CPu, caudate-putamen; NAc, nucleus accumbens. 
reactivity, positive nuclei were counted by using IPLab (version 3.5) software (Scanalytics, Billerica, MA). Phosphoimages were quantified using Image Gauge software (v3.46, Fujifilm, Stamford, CT). Hybridization signal was measured bilaterally for each rat by tracing $4-6$ sections and calculating an averaged photo stimulated luminescence (PSL) over the 4-6 sections for each animal group. At the higher magnification level, the number of cell profiles per field $(200 \times 200 \mu \mathrm{m})$ containing preproenkephalin or preprodynorphin mRNA and c-Fos immunoreactivity was calculated. A neuron was considered double labeled when its nucleus was brown and contained an aggregation of silver particles clearly above the immediately surrounding background. Background was evaluated from slides hybridized with sense probes. Double-labeled cells were counted in a total of 2-3 nonoverlapping fields per four nonadjacent sections per rat (with a separation of at least $100 \mu \mathrm{m}$ between the sections, to avoid repeated counting of the same cells). Material was analyzed and photographed under bright field (for c-Fos immunoreactivity) or epiluminescence (for mRNA signal) microscopy using a Nikon Eclipse E 800 microscope with $20 \times$ objective lenses. Images were opened and processed with a Photoshop 5.5 program (Adobe, Seattle, WA). Figure 1 shows a schematic drawing of rat brain section at the level of brain areas analyzed for c-Fos immunohistochemistry and preproenkephalin or preprodynorphin mRNA in situ hybridization. Non-paired Student's $t$-test was used for statistical analysis.
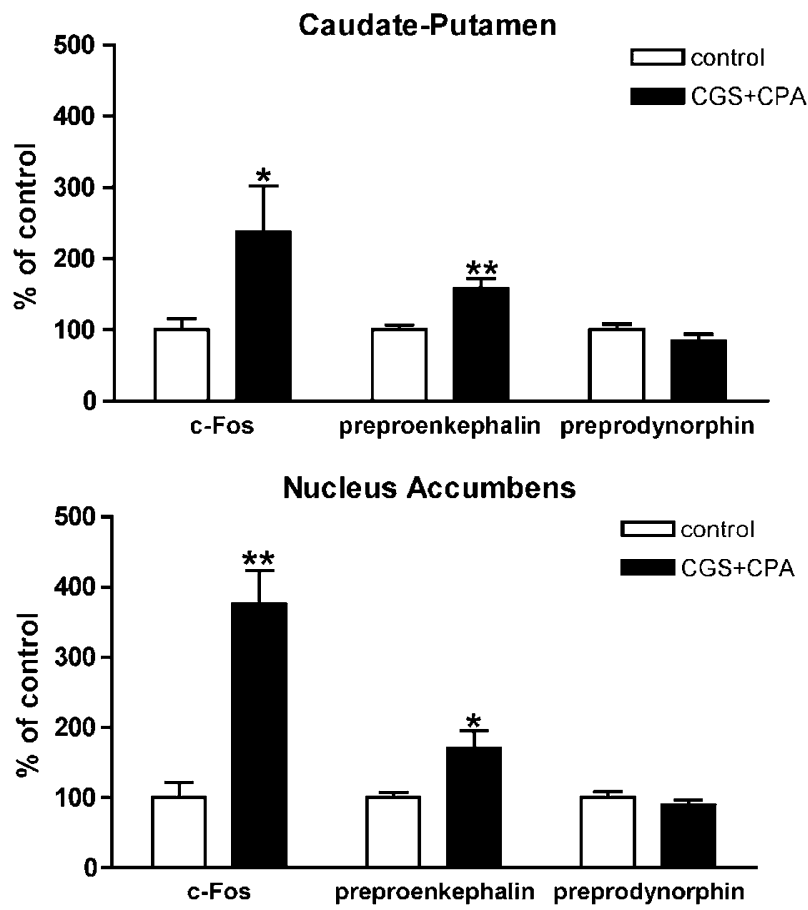

Figure 2 Quantification of C-Fos positive nuclei and the expression of preproenkephalin and preprodynorphin mRNA in the caudate-putamen and nucleus accumbens after administration of saline (control) or the $A_{2 A}$ receptor agonist CGS $21680\left(0.5 \mathrm{mg} / \mathrm{kg}\right.$ i.p.) plus the $A_{1}$ receptor agonist CPA $(0.3 \mathrm{mg} / \mathrm{kg}$ i.p.) (CGS + CPA). The results are expressed as means + SEM ( $n=5-6 /$ group) of the percentage values from control animals. * and **: significantly different compared with controls (nonpaired Student's $t$ test: $p<0.05$ and $<0.0$ I, respectively).

\section{RESULTS}

Co-Administration of $A_{1}$ and $A_{2 A}$ Receptor Agonists Induces Striatal $c$-fos and Preproenkephalin Expression

As previously reported (Karcz-Kubicha et al, 2003), coadministration of CGS $21680(0.5 \mathrm{mg} / \mathrm{kg}$ i.p. $)$ and CPA $(0.3 \mathrm{mg} / \mathrm{kg}$ i.p. $)$ induced a significant increase in the number of c-Fos positive nuclei both in the NAc (above threefold increase) and the $\mathrm{CPu}$ (above twofold increase), compared to control, saline-treated animals (non-paired Student's 't $t$-test: $p<0.01$ and $<0.05$, respectively; $n=6 /$ group; Figure 2). The number of c-Fos positive nuclei in the NAc and $\mathrm{CPu}$ of the saline-treated animals was (in means \pm SEM) $91 \pm 7$ and $76 \pm 5$, respectively. Furthermore, co-administration of CGS 21680 and CPA induced a 50\% increase of preproenkephalin mRNA expression in the NAc and $\mathrm{CPu}$ (non-paired Student's ' $t$ '-test: $p<0.05$ and $<0.01$, respectively; $n=6$ /group; Figures 2 and 3). On the other hand, no significant differences of striatal preprodynorphin mRNA expression were observed between animals treated with CGS 21680 plus CPA and controls (Figures 2 and 3). Administration of either CGS 21680 (0.5 mg/kg i.p.) or CPA $(0.3 \mathrm{mg} /$ $\mathrm{kg}$ i.p.) did not induce any significant change in the striatal expression of $c$-fos, preproenkephalin or preprodynorphin (Figure 4).
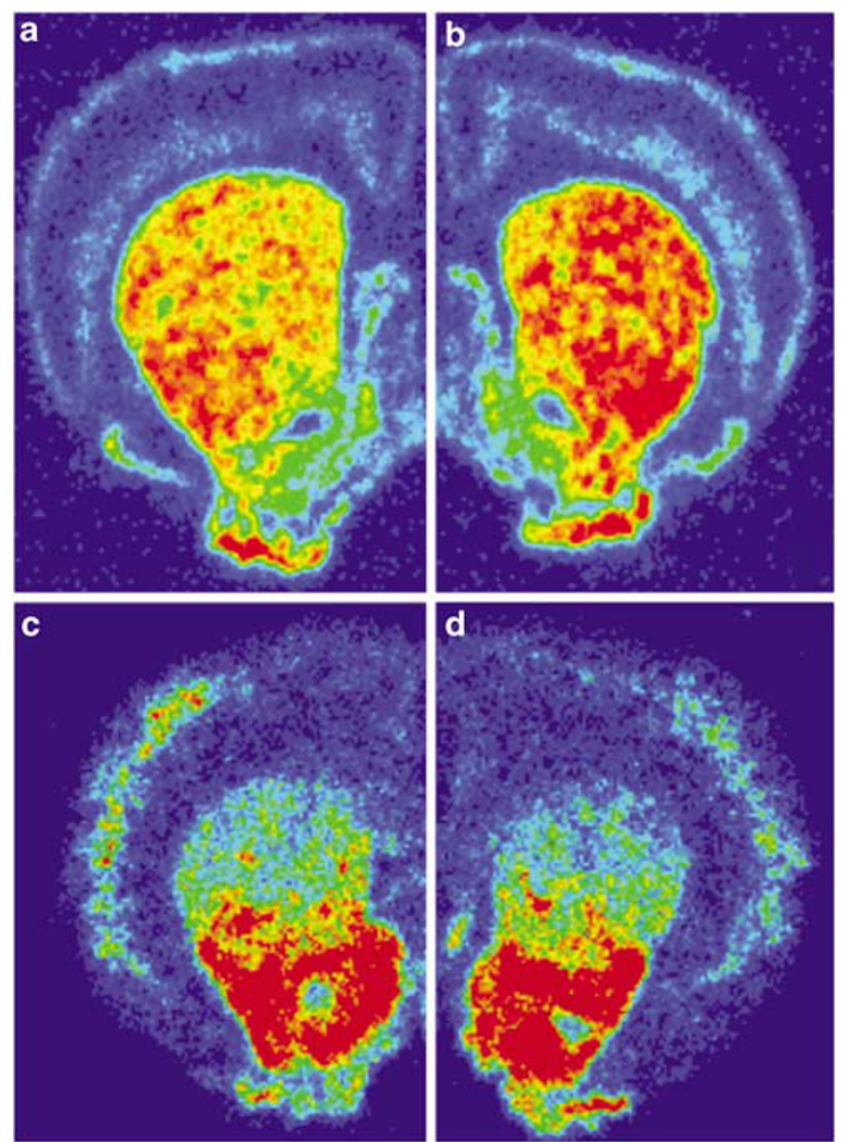

Figure 3 Expression of preproenkephalin (a, b) and preprodynorphin (c, d) mRNA in striatum after administration of saline $(a, c)$ or the $A_{2 A}$ receptor

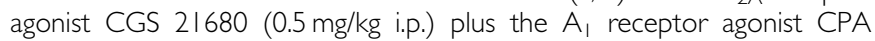
$(0.3 \mathrm{mg} / \mathrm{kg}$ i.p.) (b, d). The intensity of the in situ hybridization signal increases with the following color sequence: blue-green-yellow-red. 

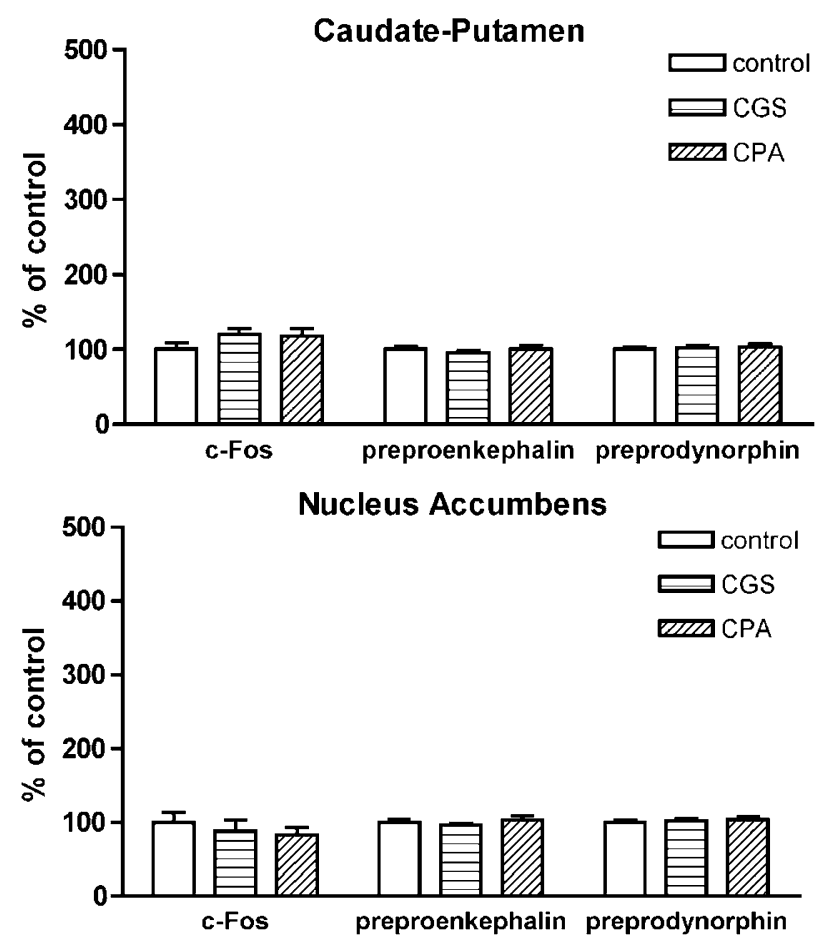

Figure 4 Quantification of c-Fos positive nuclei and the expression of preproenkephalin and preprodynorphin mRNA in the Caudate-Putamen (CPu) and Nucleus Accumbens (NAc) after administration of saline (control), the $A_{2 A}$ receptor agonist CGS 21680 (0.5 mg/kg i.p.) or the $A_{1}$ receptor agonist CPA $(0.3 \mathrm{mg} / \mathrm{kg}$ i.p.). The results are expressed as means + SEM ( $n=5-6 /$ group) of the percentage values from control animals.

\section{Co-Administration of $A_{1}$ and $A_{2 A}$ Receptor Agonists Induces $c$-fos Expression in Striatal Enkephalinergic Neurons}

The NAc was chosen for the co-localization analysis since the present and previous studies (Karcz-Kubicha et al, 2003) showed that this is the striatal region with the largest increase in $c$-fos expression after co-administration of adenosine $\mathrm{A}_{2 \mathrm{~A}}$ and $\mathrm{A}_{1}$ receptor agonists. The simultaneous detection of c-Fos immunoreactivity and preproenkephalin or preprodynorphin transcripts in the NAc showed a significant increase in the number of $\mathrm{c}$-Fos immunoreactive cells that co-express preproenkephalin in animals treated with CGS $21680(0.5 \mathrm{mg} / \mathrm{kg})$ plus CPA $(0.3 \mathrm{mg} / \mathrm{kg})$ when compared with control saline-treated animals (non-paired Student's $t$-test: $p<0.001 ; n=70$ and 32 fields for the groups treated with CGS 21680 plus CPA and saline, respectively). The same analysis showed no significant differences between the animals treated with CGS 21680 plus CPA and controls in the number of c-Fos immunoreactive cells co-expressing preprodynorphin or those lacking preproenkephalin and preprodynorphin expression (Figures 5 and 6).

\section{DISCUSSION}

In a previous study it was shown that co-administration of the $\mathrm{A}_{1}$ receptor agonist $\mathrm{CPA}$ and the $\mathrm{A}_{2 \mathrm{~A}}$ receptor agonist CGS 21680 increases the expression of the immediate-early
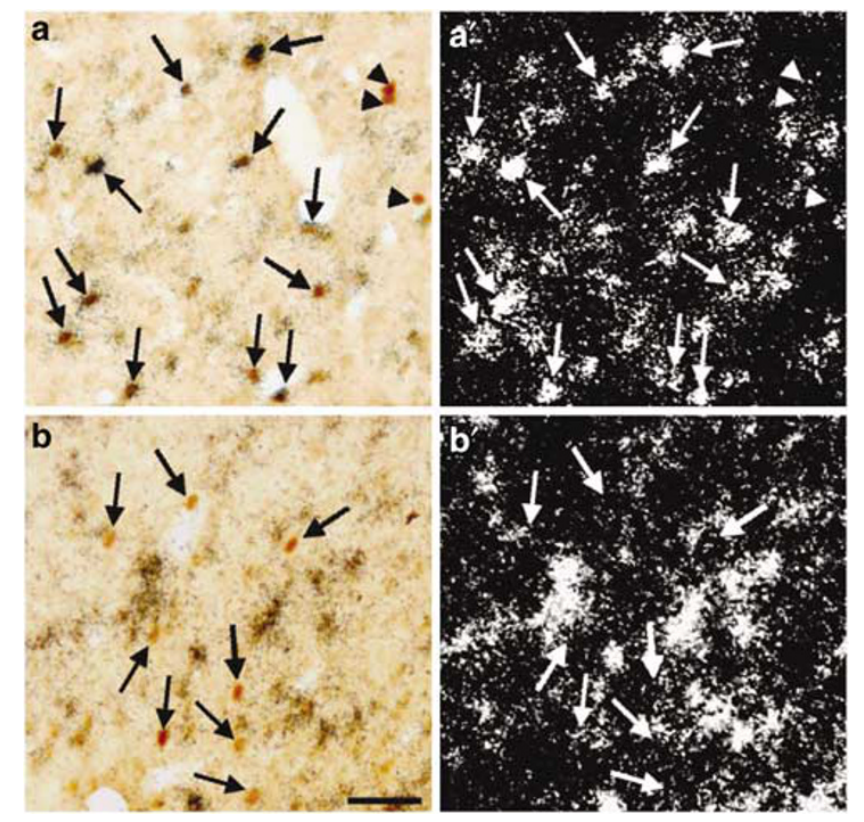

Figure 5 Simultaneous detection of c-Fos immunoreactivity $(a, b)$ and mRNA encoding preproenkephalin $\left(a^{\prime}\right)$ or preprodynorphin $\left(b^{\prime}\right)$ in NAc after treatment with the $A_{2 A}$ receptor agonist CGS 21680 (0.5 mg/kg i.p.) plus the $A_{1}$ receptor agonist CPA $(0.3 \mathrm{mg} / \mathrm{kg}$ i.p.). Bright field $(\mathrm{a}, \mathrm{b})$ and epiluminescence $\left(a^{\prime}, b^{\prime}\right)$ microscopy. $\left(a, a^{\prime}\right)$ Pairs of micrographs showing c-Fos immunoreactivity (a) and preproenkephalin mRNA ( $\left.a^{\prime}\right)$; arrows indicate examples of neurons containing c-Fos and preproenkephalin mRNA and arrow-heads indicate c-Fos immunoreactive neurons lacking preproenkephalin mRNA. (b, b') Pairs of micrographs showing c-Fos immunoreactivity (b) and preprodynorphin mRNA ( $\left.b^{\prime}\right)$; arrows indicate examples of neurons containing c-Fos immunoreactivity but lacking preprodynorphin mRNA. Scale bar $=40 \mu \mathrm{m}$.

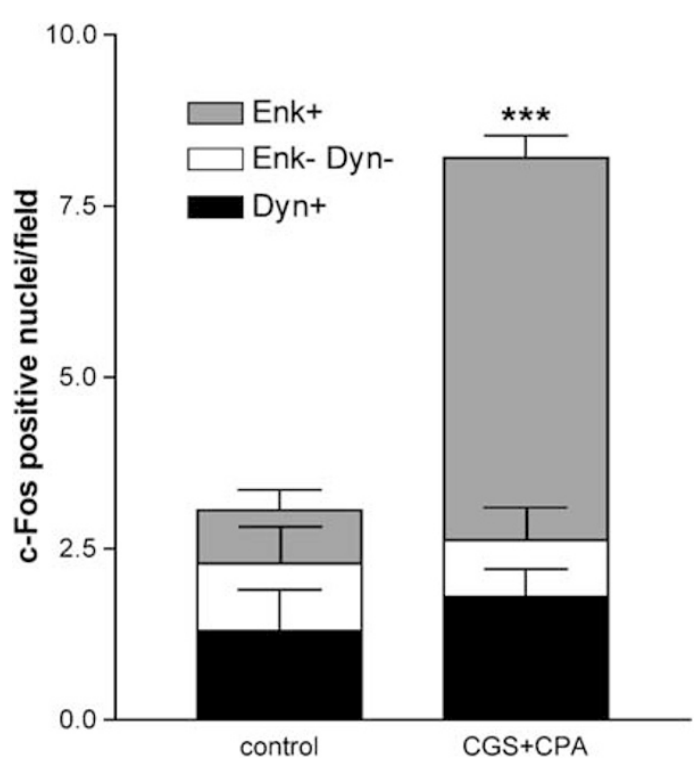

Figure 6 Quantification of c-Fos immunoreactivity from the nucleus accumbens of rats treated with the $A_{2 A}$ receptor agonist CGS 21680 $\left(0.5 \mathrm{mg} / \mathrm{kg}\right.$ i.p.) plus the $A_{1}$ receptor agonist CPA ( $0.3 \mathrm{mg} / \mathrm{kg}$ i.p.) (CGS + CPA) or with saline (control). The results are expressed as means + SEM ( $n=6 /$ group) of the number of c-Fos positive nuclei per field. Enk + and Dyn +: c-Fos positive cells expressing preproenkephalin and preprodynorphin, respectively; Enk- Dyn-: c-Fos positive cells expressing neither transcript. ****: significant increase in Enk + with CGS + CPA treatment compared to control (nonpaired Student's t-test: $p<0.00 \mathrm{I}$ ). 
gene $c$-fos in the striatum (Karcz-Kubicha et al, 2003). In the present study, we demonstrate that this increase is selective for the GABAergic enkephalinergic neurons. Furthermore, $\mathrm{A}_{1}-\mathrm{A}_{2 \mathrm{~A}}$ receptor co-stimulation induced an increase in the expression of the neuropeptide gene preproenkephalin, but not preprodynorphin. These were expected findings given the fact that GABAergic enkephalinergic neurons show the highest expression of $\mathrm{A}_{2 \mathrm{~A}}$ receptors in the brain (Schiffmann et al, 1991; Hettinger et al, 2001).

Adenosine $\mathrm{A}_{2 \mathrm{~A}}$ receptors are Gs-olf protein-coupled receptors whose main signaling pathway is adenylyl-cyclase activation, the cAMP-PKA cascade (Kull et al, 1999, 2000). Important PKA substrates include the dopamine and cyclic adenosine $3^{\prime}, 5^{\prime}$-monophosphate-regulated phophoprotein, $32 \mathrm{kDa}$ (DARPP-32) and the nuclear constitutive transcription factor cAMP response element binding protein (CREB) (Greengard et al, 1999). DARPP-32 acts as an amplificatory mechanism of the cAMP-PKA cascade and it has been suggested to be essential for striatal $\mathrm{A}_{2 \mathrm{~A}}$ receptor signaling (Svenningsson et al, 1998; Lindskog et al, 2002). The catalytic subunits of PKA can diffuse into the nucleus and induce cellular gene expression by phosphorylating CREB. The immediate-early gene $c$-fos and the preproenkephalin gene are very well-studied target genes the promoters of which contain consensus sites for pCREB binding (Borsook and Hyman, 1995; Herdegen and Leah, 1998). Thus, $A_{2 A}$ receptor stimulation can potentially activate the cAMP-PKA cascade and increase the expression of immediate-early genes and the preproenkephalin gene, which codes for the precursor of enkephalin.

$A_{2 A}$ and $D_{2}$ receptors form heteromeric complexes with reciprocal antagonistic interactions that regulate the function of the GABAergic enkephalinergic neurons (Ferré et al, 1991, 1993, 1997, 2003; Agnati et al, 2003; Canals et al, 2003; Kamiya et al, 2003; Ciruela et al, 2004; Woods and Ferré, 2005). Stimulation of $A_{2 A}$ receptors decreases the affinity of $\mathrm{D}_{2}$ receptors for agonists by means of an intramembrane interaction (Ferré et al, 1991), while stimulation of $\mathrm{D}_{2}$ receptors inhibits $\mathrm{A}_{2 \mathrm{~A}}$ receptor-induced activation of adenylyl-cyclase (Kull et al, 1999; Hillion et al, 2002). By means of the strong antagonistic $\mathrm{D}_{2}-\mathrm{A}_{2 \mathrm{~A}}$ receptor interaction at the adenylyl cyclase level, and due to the existence of a tonic effect of dopamine on $\mathrm{D}_{2}$ receptors, under normal conditions $\mathrm{A}_{2 \mathrm{~A}}$ receptors are practically unable to activate the cAMP-PKA signaling pathway (Agnati et al, 2003; Ferré et al, 2003, 2004). In fact, the systemic administration of $A_{2 A}$ receptor antagonists produces either no effect or a modest decrease in the striatal expression of $c$-fos or preproenkephalin (Le Moine et al, 1997; Pinna et al, 1997; Aoyama et al, 2002; Carta et al, 2002; Karcz-Kubicha et al, 2003; Wardas et al, 2003). It must also be pointed out that some studies suggest that $\mathrm{A}_{2 \mathrm{~A}}$ and $\mathrm{D}_{2}$ receptor can interact synergistically, with stimulation of $\mathrm{D}_{2}$ receptors potentiating the effects of $\mathrm{A}_{2 \mathrm{~A}}$ receptor stimulation. These conditions seem to depend on the isoform of adenylyl cyclase involved or on the interruption of a previous long-term exposure to $\mathrm{D}_{2}$ receptor agonists (Yao et al, 2002; Kudlacek et al, 2003; Vortherms and Watts, 2004). In any case, the main isoform of adenylyl cyclase in the striatum is AC5, and co-stimulation of $\mathrm{G}_{\mathrm{s}^{-}}$and $\mathrm{G}_{\mathrm{i}}$-coupled receptors shows antagonistic interactions at the AC5 level (Chern, 2000; Defer et al, 2000). In fact, $\mathrm{D}_{2}$ receptor stimulation has been shown to counteract cAMP accumulation induced by $A_{2 A}$ receptor stimulation in membrane preparations from mouse striatum (Lee et al, 2002).

The effects on the striatal expression of $c$-fos and preproenkephalin observed in the present study depend on the concomitant administration of $\mathrm{A}_{1}$ and $\mathrm{A}_{2 \mathrm{~A}}$ agonists, since neither agonist produced any effect when administered alone. Nevertheless, in our previous study, the $A_{1}$ receptor agonist CPA alone induced a significant increase in $c$-fos expression in the medial part of the NAc (Karcz-Kubicha et al, 2003). The simultaneous analysis of the medial and lateral parts of the NAc might have diluted such a local effect of CPA. We have previously suggested that the inability of the $\mathrm{A}_{2 \mathrm{~A}}$ receptor agonist CGS 21680 to induce an increase in the striatal expression of $c$-fos depends on its ability to produce striatal dopamine release (Karcz-Kubicha et al, 2003), which further stimulates $\mathrm{D}_{2}$ receptors and, therefore, antagonizes the effects of $\mathrm{A}_{2 \mathrm{~A}}$ receptor stimulation by the exogenous agonist. CPA administration was shown to decrease the striatal extracellular concentration of dopamine and to counteract CGS 21680-induced dopamine release (Karcz-Kubicha et al, 2003). Therefore, this local-circuit mechanism can explain why activation of adenosine $A_{1}$ receptors allows $A_{2 A}$ receptors to overcome the inhibitory effect of $D_{2}$ receptors and induce striatal expression of $c$-fos and preproenkephalin. We have recently studied the mechanisms involved in the $A_{2 A}$ receptor-mediated striatal dopamine release and suggested that it depends on glutamate neurotransmission (facilitation of glutamate release by the stimulation of $\mathrm{A}_{2 \mathrm{~A}}$ receptor localized in striatal glutamatergic terminals) and NMDA receptor stimulation (facilitation of dopamine release by spillover of glutamate and stimulation of NMDA receptors localized in dopaminergic terminals) (Quarta et al, 2004). Concomitant administration of an $\mathrm{A}_{1}$ receptor agonist counteracts CGS 21680-induced dopamine release (Karcz-Kubicha et al, 2003) most probably by indirect inhibitory effects on glutamate release (Quarta et al, 2004) and direct inhibitory effects on dopamine release (Borycz et al, in preparation). Whatever the mechanisms involved, concomitant $\mathrm{A}_{1}$ receptor stimulation, which is actually what occurs with endogenous adenosine release, enables $A_{2 A}$ receptor stimulation to produce a significant increase in the striatal expression of $c$-fos and preproenkephalin.

The present results underscore the role of adenosine in the activation of gene expression in the GABAergic enkephalinergic neuron. Previous studies showed evidence for an opposite modulatory role of adenosine in the other major striatal neuronal element, the GABAergic dynorphinergic neuron, where activation of $A_{1}$ receptors attenuates dopamine $D_{1}$ receptor-mediated release of GABA and increase in the striatal expression of the immediate-early genes NGFI-A, c-fos and jun-B (Ferré et al, 1996, 1999). Therefore, under physiological conditions of increased adenosine release, a preferential activation of GABAergic enkephalinergic $v s$ GABAergic dynorphinergic neurons must take place. Since this activation has consequences at the gene level, adenosine could selectively facilitate plastic changes in the synapses of the GABAergic enkephalinergic neurons, which can have implications for drug therapy in neuropsychiatric disorders and drug abuse. For instance, there is experimental evidence for the existence of selective 
gene expression in GABAergic enkephalinergic neurons during sensitization to the behavioral effects of psychostimulants (Uslaner et al, 2001). In fact, genetic inactivation of $\mathrm{A}_{2 \mathrm{~A}}$ receptors has been reported to attenuate amphetamineinduced behavioral sensitization (Chen et al, 2003).

\section{ACKNOWLEDGEMENTS}

This research was supported by the Intramural Research Program of the NIH, National Institute on Drug Abuse.

\section{REFERENCES}

Agnati LF, Ferré S, Lluis C, Franco R, Fuxe K (2003). Molecular mechanisms and therapeutical implications of intramembrane receptor/receptor interactions among heptahelical receptors with examples from the striatopallidal GABA neurons. Pharmacol Rev 55: 509-550.

Aoyama S, Koga K, Mori A, Miyaji H, Sekine S, Kase H et al (2002). Distribution of adenosine $\mathrm{A}(2 \mathrm{~A})$ receptor antagonist KW-6002 and its effect on gene expression in the rat brain. Brain Res 953: $119-125$.

Backman C, Hoffer BJ, Misawa H, Morales M (2001). Cellular mRNA expression of the transcription factor NGFI-B suggests a gene regulatory role in striatal opiate-peptide neurons. Brain Res 903: 26-32.

Borsook D, Hyman SE (1995). Proenkephalin gene regulation in the neuroendocrine hypothalamus: a model of gene regulation in the CNS. Am J Physiol 269: E393-E408.

Canals M, Marcellino M, Fanelli F, Ciruela F, de Benedetti P, Goldberg S et al (2003). Adenosine A2A-dopamine D2 receptorreceptor heteromerization. Qualitative and quantitative assessment by fluorescence and bioluminescence energy transfer. J Biol Chem 278: 46741-46749.

Carta AR, Pinna A, Cauli O, Morelli M (2002). Differential regulation of GAD67, enkephalin and dynorphin mRNAs by chronic-intermittent L-dopa and $\mathrm{A} 2 \mathrm{~A}$ receptor blockade plus L-dopa in dopamine-denervated rats. Synapse 44: 166-174.

Chen JF, Moratalla R, Yu L, Martin AB, Xu K, Bastia E et al (2003). Inactivation of adenosine $\mathrm{A} 2 \mathrm{~A}$ receptors selectively attenuates amphetamine-induced behavioral sensitization. Neuropsychopharmacology 28: 1086-1095.

Chern Y (2000). Regulation of adenylyl cyclase in the central nervous system. Cell Signal 12: 195-204.

Ciruela F, Burgueno J, Casado V, Canals M, Marcellino D, Goldberg SR et al (2004). Combining nass spectrometry and pull-down techniques for the study of receptor heteromerization. Direct epitope-epitope electrostatic interactions between adenosine A2A and dopamine D2 receptors. Anal Chem 76: 5354-5363.

Defer N, Best-Belpomme M, Hanoune J (2000). Tissue specificity and physiological relevance of various isoforms of adenylyl cyclase. Am J Physiol Renal Physiol 279: F400-F416.

Ferré S, Ciruela F, Canals M, Marcellino D, Burgueno J, Casado V et al (2004). Adenosine A2A-dopamine D2 receptor-receptor heteromers. Targets for neuro-psychiatric disorders. Parkinsonism Relat Disord 10: 265-271.

Ferré S, Ciruela F, Woods AS, Canals M, Burgueno J, Marcellino D et al (2003). Glutamate mGlu5-adenosine A2A-dopamine D2 receptor interactions in the striatum. Implications for drug therapy in neuropsychiatric disorders and drug abuse. Curr Med Chem-Central Nerv Systems Agents 33: 1-26.

Ferré S, Fredholm BB, Morelli M, Popoli P, Fuxe K (1997). Adenosine-dopamine receptor-receptor interactions as an integrative mechanism in the basal ganglia. Trends Neurosci 20: $482-487$.
Ferré S, O’Connor WT, Fuxe K, Ungerstedt U (1993). The striopallidal neuron: a main locus for adenosine-dopamine interactions in the brain. J Neurosci 13: 5402-5406.

Ferré S, O'Connor WT, Svenningsson P, Bjorklund L, Lindberg J, Tinner B et al (1996). Dopamine D1 receptor-mediated facilitation of GABAergic neurotransmission in the rat strioentopenduncular pathway and its modulation by adenosine A1 receptor-mediated mechanisms. Eur J Neurosci 8: 1545-1553.

Ferré S, Rimondini R, Popoli P, Reggio R, Pezzola A, Hansson AC et al (1999). Stimulation of adenosine A1 receptors attenuates dopamine D1 receptor-mediated increase of NGFI-A, c-fos and jun-B mRNA levels in the dopamine-denervated striatum and dopamine D1 receptor-mediated turning behaviour. Eur J Neurosci 11: 3884-3892.

Ferré S, von Euler G, Johansson B, Fredholm BB, Fuxe K (1991). Stimulation of high-affinity adenosine A2 receptors decreases the affinity of dopamine D2 receptors in rat striatal membranes. Proc Natl Acad Sci USA 88: 7238-7241.

Gerfen CR (2000). Molecular effects of dopamine on striatalprojection pathways. Trends Neurosci 23: S64-S70.

Gerfen CR (2004). Basal ganglia. In: Paxinos G (ed). The Rat Nervous System. Elsevier: San Diego. pp 455-508.

Greengard P, Allen PB, Nairn AC (1999). Beyond the dopamine receptor: the DARPP-32/protein phosphatase-1 cascade. Neuron 23: 435-447.

Herdegen T, Leah JD (1998). Inducible and constitutive transcription factors in the mammalian nervous system: control of gene expression by Jun, Fos and Krox, and CREB/ATF proteins. Brain Res Brain Res Rev 28: 370-490.

Hettinger BD, Lee A, Linden J, Rosin DL (2001). Ultrastructural localization of adenosine A2A receptors suggests multiple cellular sites for modulation of GABAergic neurons in rat striatum. J Comp Neurol 43: 331-346.

Hillion J, Canals M, Torvinen M, Casado V, Scott R, Terasmaa A et al (2002). Coaggregation, cointernalisation, and codesensitization of adenosine A2A receptors and dopamine D2 receptors. J Biol Chem 277: 18091-18097.

Kamiya T, Saitoh O, Yoshioka K, Nakata H (2003). Oligomerization of adenosine A2A and dopamine D2 receptors in living cells. Biochem Biophys Res Commun 306: 544-549.

Karcz-Kubicha M, Quarta D, Hope BT, Antoniou K, Muller CE, Morales $\mathrm{M}$ et al (2003). Enabling role of adenosine A1 receptors in adenosine A2A receptor-mediated striatal expression of c-fos. Eur J Neurosci 18: 296-302.

Kudlacek O, Just H, Korkhov VM, Vartian N, Klinger M, Pankevych $\mathrm{H}$ et al (2003). The human D2 dopamine receptor synergizes with the A2A adenosine receptor to stimulate adenylyl cyclase in PC12 cells. Neuropsychopharmacology 28: 1317-1327.

Kull B, Ferré S, Arslan G, Svenningsson P, Fuxe K, Owman C et al (1999). Reciprocal interactions between adenosine A2A and dopamine D2 receptors in Chinese hamster ovary cells co-transfected with the two receptors. Biochem Pharmacol 58: 1035-1045.

Kull B, Svenningsson P, Fredholm BB (2000). Adenosine A(2A) receptors are colocalized with and activate $\mathrm{g}(\mathrm{olf})$ in rat striatum. Mol Pharmacol 58: 771-777.

Lee KW, Hong JH, Choi IY, Che Y, Lee JK, Yang SD et al (2002). Impaired D2 dopamine receptor function in mice lacking type 5 adenylyl cyclase. J Neurosci 22: 7931-7940.

Le Moine C, Svenningsson P, Fredholm BB, Bloch B (1997). Dopamine-adenosine interactions in the striatum and the globus pallidus: inhibition of striatopallidal neurons through either D2 or A2A receptors enhances D1 receptor-mediated effects on c-fos expression. J Neurosci 17: 8038-8048.

Lindskog M, Svenningsson P, Pozzi L, Kim Y, Fienberg AA, Bibb JA et al (2002). Involvement of DARPP-32 phosphorylation in the stimulant action of caffeine. Nature 418: 774-778. 
Morales M, Criado JR, Sanna PP, Henriksen SJ, Bloom FE (1998). Acute ethanol induces c-Fos immunoreactivity in GABAergic neurons of the central nucleus of the amygdala. Brain Res 798: 333-336.

Pinna A, Wardas J, Cristalli G, Morelli M (1997). Adenosine A2A receptor agonists increase Fos-like immunoreactivity in mesolimbic areas. Brain Res 759: 41-49.

Quarta D, Borycz J, Solinas M, Patkar K, Hockemeyer J, Ciruela F et al (2004). Adenosine receptor-mediated modulation of dopamine release in the nucleus accumbens depends on glutamate neurotransmission and $N$-methyl-D-aspartate receptor stimulation. J Neurochem 91: 873-880.

Schiffmann SN, Jacobs O, Vanderhaeghen JJ (1991). Striatal restricted adenosine A2 receptor (RDC8) is expressed by enkephalin but not by substance $\mathrm{P}$ neurons: an in situ hybridization histochemistry study. J Neurochem 57: 1062-1067.

Svenningsson P, Lindskog M, Rognoni F, Fredholm BB, Greengard P, Fisone $G$ (1998). Activation of adenosine A2A and dopamine D1 receptors stimulates cyclic AMP-dependent phosphorylation of DARPP-32 in distinct populations of striatal projection neurons. Neuroscience 84: 223-228.

Uslaner J, Badiani A, Norton CS, Day HE, Watson SJ, Akil H et al (2001). Amphetamine and cocaine induce different patterns of c-fos mRNA expression in the striatum and subthalamic nucleus depending on environmental context. Eur J Neurosci 13: 1977-1983.

Vortherms TA, Watts VJ (2004). Sensitization of neuronal A2A adenosine receptors after persistent D2 dopamine receptor activation. J Pharmacol Exp Ther 308: 221-227.

Wardas J, Pietraszek M, Dziedzicka-Wasylewska M (2003). SCH 58261, a selective adenosine A2A receptor antagonist, decreases the haloperidol-enhanced proenkephalin mRNA expression in the rat striatum. Brain Res 977: 270-277.

Woods AS, Ferré S (2005). Amazing stability of the argininephosphate electrostatic interaction. J Proteome Res 4: 1397-1402.

Yao L, Arolfo MP, Dohrman DP, Jiang Z, Fan P, Fuchs S et al (2002). betagamma Dimers mediate synergy of dopamine D2 and adenosine A2 receptor-stimulated PKA signaling and regulate ethanol consumption. Cell 109: 733-743. 